\title{
Mogelijkheden en beperkingen van een 'sociaal humanisme'. Omtrent ideologische conflicten binnen het Vlaams Humanistisch Verbond (1951-1961)
}

Jan Fransen, wetenschappelijk medewerker BRUT-VUB

Tot op vandaag is het Humanistisch Verbond (HV) in het Belgische maatschappelijke leven een minoritaire groepering gebleven. Toch hadden de stichters ervan in 1951 het idee gekoesterd het toenemend aantal kerkelijke 'afvalligen' achter het humanistische vaandel te krijgen. Een groot hiaat ontstond aldus tussen de oorspronkelijke verzuchtingen van de 'modeme humanisten' en het aantal onkerkelijken die men daadwerkelijk over de toetredingsdrempel kon brengen. Dit zette mij, als licentiaatstudent geschiedenis, ertoe aan voor die discrepantie een verklaring te gaan zoeken bij de vroegste historische wortels van het $H V^{(1)}$. Veel bleek uiteindelijk verband te houden met het doorgedreven individualisme en intellectualisme van het stichtende establishment van het $H V$. De sociale dimensie werd daardoor onvermijdelijk het kind van de rekening. Dat werd reeds aangetoond in een ander artikel ${ }^{(2)}$. Het wordt hier in samenvattende vorm toegelicht als inleiding op het centrale thema van onderhavig artikel. Daarin is het de bedoeling aan te tonen dat de elitaire geesteshouding van de HV-elite geenszins onaangevochten bleef. Reeds eind jaren '50 ontwikkelden zich de contouren van een altermatief dat veelal werd omschreven als een 'sociaal humanisme' als antipode van het vigerende 'individualistische humanisme'. Dit artikel gaat dan ook in op de confrontatie van die twee ideologische tendensen die in het jaar 1960-'61 haar eerste culminatiepunt kende.

Ontstaan, verspreiding en crisis van het individualistische humanisme (1950-'58)

\section{De Nederlandse bakermat}

In Nederland werd de onkerkelijkheid van oudsher gedragen door de in 1856 opgerichte vrijdenkersvereniging De Dageraad en de socialistische partij SDAP. De Tweede Wereld- oorlog betekende daarin echter een breekpunt. De Dageraad slaagde er na de oorlog duidelijk niet meer in met haar klassieke discours het toenemende aantal onkerkelijken ${ }^{(3)}$ tot de verbeelding te spreken. Het radicale anti-klerikalisme dat vooral de strijd promootte van de rede tégen de godsdiensten begon velen als een anachronisme in de oren te klinken ${ }^{(4)}$. Vooral 
het feit dat gelovigen en ongelovigen aan eenzelfde zeel trokken in de strijd tegen het nazisme stimuleerde dat gevoel. Bovendien bleek het anti-klerikalisme ook in het politieke leven weg te ebben. In sociaal-democratische milieus trachtte men de klassieke antithese tussen gelovigen en ongelovigen op te heffen met het oog op een eensgezind front ter verwezenlijking van de dringende naoorlogse economische en politieke hervormingen. Militant anti-klerikalisme stond een dergelijke samensmelting uiteraard in de weg en werd dan ook niet langer een opportune optie bevonden ${ }^{(5)}$. Een levensbeschouwelijk vacuüm lag daarmee open. Met de oprichting van het HV in 1946 door Jaap Van Praag en enkele andere intellectuelen kwam men dan ook aan die nieuwe noden tegemoet.

Centrale doelstelling van de nieuwe vereniging was het creëren van een sociale levensruimte náást die van de bestaande Kerken, voor mensen die niet langer genoegen namen met wat de godsdienstige moraal hen voorschreef, zónder die Kerken evenwel aan te vallen. Er moest een eigen positieve humanistische ethiek worden ontwikkeld die de onkerkelijke mens in staat zou stellen zich op niet-godsdienstige basis te bezinnen over de grondwaarden van zijn eigen bestaan. Daarmee wilde men de alomtegenwoordige opvatting ontkrachten dat onkerkelijken per definitie mensen waren zonder enige geestelijke diepgang ${ }^{(6)}$. Die gedachtengang wilde men ook doordrukken in de maatschappelijke praktijk door het kerkelijke monopolie op het geestelijke raadswerk op diverse terreinen van het maatschappelijke leven, zoals ziekenhuizen, gevangenissen, bejaardenzorg enz... te breken.

Begin 1950 was ook bij ons het klimaat gunstig voor een dergelijk initiatief. Dat het Nederlandse pragmatisme (een sociale levensruimte naast de bestaande Kerken zonder ze aan te vallen) bij ons navolging vond hoeft om verschillende redenen niet te verwonderen. Gezien de zwakke positie van de Vlaamse vrijzinnigheid en de traditionele sterkte van de katholieke zuil zou ook hier gematigheid opportuner zijn dan de stugge papenvreterij van de klassieke vrijdenkersbeweging. Die tendens manifesteerde zich reeds duidelijk eind jaren ' 30 in de West-Vlaamse vrijzinnige pressiegroep De Vrienden van het Officieel Onderwijs. In tegenstelling tot de toenmalige vrijdenkersbeweging, die nog steeds streefde naar de vestiging van een hegemonische laïciteit, keerde deze groep zich pragmatischerwijze niet langer tegen de subsidiëring van het katholieke net, hopend aldus het zwaartepunt van het schoolpolitieke debat te verleggen naar de broodnodige expansie van lager en middelbaar onderwijs in streken die dat tot dan toe ontbeerden. Het was de eerste uiting van wat Jeffrey Tyssens "een geleidelijk op autonome basis groeiende Vlaams-viijzinnige tegencultuur" noemde ${ }^{(7)}$. De Tweede Wereldoorlog luidde trouwens, net als voor de Nederlandse De Dageraad, de definitieve ondergang in van die klassieke vrijdenkersbeweging. Tussen 1945 en 1951 slaagde men er in Vlaanderen niet in tot een degelijk georganiseerde vrijdenkersactiviteit te komen. De uiteindelijk in 1951 opgerichte Vrijdenkersunie beperkte zich nog slechts tot de uitgave van De Vrijdenker, het beheer van de Antwerpse afdeling van de Belgische Vereniging ter Bevordering van de Lijkverbranding en de coordinatie van de Feesten van de Vrijzinnige Jeugd ${ }^{(8)}$. Buiten de Antwerpse metropool werden geen geconsolideerde vrijdenkerskernen meer opgericht.

Net als bij de noorderburen was aldus de voedingsbodem aanwezig voor de oprichting van een nieuwe organisatie die de onkerkelijken van een levensbeschouwelijk onderdak zou voorzien. Het jaar 1950 vormde daartoe om 
meerdere redenen een goede aanleiding. De Kerk trachtte toen haar interne cohesie opnieuw te versterken met een reeks pauselijke encyclieken culminerend in de beruchte $\mathrm{Hu}$ mani Generis. Ook de polarisering tussen links en rechts naar aanleiding van de Koningskwestie en de eruit voortvloeiende absolute CVP-meerderheid, kon de noodzaak van een $\mathrm{HV}$ alleen maar bevestigen ${ }^{(9)}$.

\section{Het Vlaamse Humanistisch Verbond als resultante van maçonnieke initiatieven}

Sedert de jaren ' 30 van de $19 \mathrm{e}$ eeuw bestond er in België een complexe symbiose tussen vrijmetselarij en vrijzinnigheid. De sterke katholieke machtsaanspraken in het postrevolutionaire België hadden immers gezorgd voor een identificatie tussen liberalisme, anti-klerikalisme en vrijmetselarij. De loges groeiden in die context uit tot ontmoetingscentra van mensen die een voorkeur hadden voor een lekenmaatschappij onttrokken aan de macht van de Kerk ${ }^{(10)}$. Het behoorde van dan af aan tot één van de essentiële taken van de vrijmetselarij om de geestelijke en morele elite van de vrijzinnigheid te verenigen en te zorgen voor haar verdere filosofische ontplooiing. Het was dan ook niet zo verwonderlijk dat juist in die kringen er na de oorlog een opmerkelijke gevoeligheid was voor het bestaande vacuüm op levensbeschouwelijk vlak.

De eerste aanzetten tot de stichting van een $\mathrm{HV}$ werden gegeven in Vlaams-maçonnieke milieus. Het eigenlijke initiatief kwam van Robert Dille ${ }^{(1)}$, lid van de Antwerpse loge Marnix van Sint-Aldegonde. Binnen deze loge verwierf hij tevens de steun van Karel Cuypers, Louis Van Laar, Frans Camerlinckx en A.B. ${ }^{(12)}$. Daarna polste hij de interesse van de recentere loges De Zwijger in het Gentse en Balder in het Brusselse. Voor de eerste zegden
Romain Ruyssen, Lucien De Coninck, Herman Thiery en Louis Hebbelinck toe ${ }^{113}$; voor de laatste Leopold Flam, Reimond Herreman, Marcel Hofmans en Gaston Bouckaert ${ }^{(14)}$. Zij vormden de kleine groep van ingewijden die reeds op 28 maart 1951 het HV boven de doopvont hielden (sic). Daarmee werd, in de woorden van initiatiefnemer Dille, gestalte gegeven aan een "praktische profane vrijmetselarij" ${ }^{(15)}$. Wat bedoelde hij daar nu mee?

Er werd reeds op gewezen dat de orde van oudsher mobiliserend werkte voor een beperkte vrijzinnige elite die hier een milieu vond waarin ze de kans had een positieve levensbeschouwing te ontplooien op niet-godsdienstige basis. De broeders die het HV stichtten waren er zich echter van bewust dat de massa vooralsnog van die mogelijkheid verstoken bleef. Wat de vrijmetselarij op dat vlak dus was voor een intellectuele, vrijzinnige elite, zou het $\mathrm{HV}$ voor de grotere buitenkerkelijke massa ${ }^{(16)}$ moeten worden. De stichtende vrijmetselaars vormden aldus een profaan milieu waar de humanist nu in de mogelijkheid werd gesteld om voor zichzelf aan een positieve, niet-confessionele levensbeschouwing te werken zonder daarom noodzakelijkerwijze vrijmetselaar te zijn.

Een belangrijk gevolg daarvan was dat het HV de stempel zou dragen van de vrijmetselaarsideologie. Voor de vrijmetselaar geldt absolute gewetensvrijheid waaraan onder geen beding getornd mag worden. Centraal voor het genootschap staat het streven naar universele broederschap, waarbij de logeleden de divergenties trachten te overstijgen die hen in de buitenwereld verdelen. Het $\mathrm{HV}$, als maçonniek initiatief, reflecteerde in zijn beginselverklaring dan ook enkel universele en heel vage waarden die het iedereen mogelijk bleven maken volledig naar eigen goeddunken een levensbeschouwing op te bouwen. Net als de vrijmetselaar zou de humanist steeds uitsluitend denken en hande- 
len ten individuelen titel en mocht hij in zijn gewetensvrijheid geenszins beknot worden. Eensgezinde standpunten in maatschappelijke zin waren daarmee strijdig en werden dan ook achterwege gelaten. Vandaar dat gesproken wordt van een 'individualistisch humanisme'om de vigerende ideologie van het toenmalige $\mathrm{HV}$ te karakteriseren.

\section{Uitbreiding en crisis van het individualistisch humanisme}

Het HV legde in de jaren ' 50 een vrij omvangrijke organisatorische activiteit aan de dag. Niet minder dan tien afdelingen zagen het licht: Antwerpen, Gent, Brussel, Brugge, Mechelen, Limburg, Boom, Leuven, Oostende en Blankenberge. Meestal ging het initiatief uit van mensen werkzaam in het hoger secundair onderwijs en meer in het bijzonder van mensen betrokken bij het recente vak van de niet-confessionele moraal ${ }^{(17)}$. De manier waarop deze afdelingen zich in die eerste jaren naar buiten toe profileerden lag duidelijk in het verlengde van de aspiraties van het stichtende establishment van het HV. De voornaamste activiteit bestond uit het organiseren van voordrachten en debatten veelal gewijd aan de uitdieping van wat ook wel het 'wetenschappelijke humanisme'werd genoemd. In concreto wilde dit zeggen lezingen door bij voorkeur academici, in de materie waarin ze professioneel onderlegd waren ${ }^{(18)}$. Het resultaat dat men met dergelijke aanpak wilde bereiken was de mensen bewust maken van de diversiteit aan meningen en onderwerpen die het humanisme herbergde. De vrije discussie prevaleerde in die gedachtengang duidelijk op het verlangen naar enige vorm van synthese van het humanistische gedachtengoed, want zulks zou afbreuk kunnen doen aan de absolute gewetensvrijheid van de humanist. Het verbondsblad Diogenes, dat verscheen van 1953 tot 1958 en oorspronkelijk beschouwd werd als een enorm belangrijk initiatief met het oog op ledenwerving, bevatte dan ook enkel artikels met een in hoofdzaak probleemstellend karakter. Elke duidelijker omlijning van het 'moderne humanisme' bleef een absoluut taboe.

Een belangrijke vraag die zich hierbij opdringt is of men bij deze aanpak ook de doorsneeonkerkelijke heeft aangesproken. Hoewel voor de eerste jaren geen echte cijfergegevens teruggevonden konden worden is het wel zo dat verschillende archiefstukken wijzen op een zeer bescheiden stijging van het aantal leden. De verwachte toeloop werd het niet. Die evolutie wordt inderdaad bevestigd door het eerste cijfer dat voorhanden is, meer bepaald voor het jaar 1956 en dat wijst op een kleine 1500 leden ${ }^{(19)}$. In 1958 bleef dat aantal stabiel. Toen leverden de oudste afdelingen Gent en Antwerpen met respectievelijk 440 en 328 leden zowat de helft van het totale ledental dat over negen afdelingen verspreid was ${ }^{(20)}$. In 1959 reeds werd voor het eerst gesproken van een terugval ${ }^{(21)}$. Het jaar daarop werd die neergaande trend bevestigd. In het gros van de afdelingen vielen zowel het antal belangstellenden als de activiteiten terug. Daar waar bijvoorbeeld 1956 nog goed was voor welgeteld 68 debatten en voordrachten telde men er in 1960 nog slechts 43 voor hetzelfde aantal afdelingen ${ }^{(22)}$. Het HV leek gedoemd een uitermate bescheiden elitegroep te blijven. Eerder had men gehoopt met de initiatieven in verband met de moraalcursus en met eigen $\mathrm{TV}$ - en radioprogramma's een doorbraak te forceren. Het gebrek aan representativiteit echter maakte grote successen op deze terreinen bij voorbaat onmogelijk. Met een totaal van 1500 leden kon men inderdaad bezwaarlijk aanspraak maken op de vertegenwoordiging van de onkerkelijke bevolkingsgroep. Sommigen begonnen de in- 
dividualistische aanpak van het $\mathrm{HV}$-establishment daarvoor verantwoordelijk te stellen. Het was ook in de jaren ' 59 tot ' 61 dat zich een heel nieuwe invulling van het humanisme aandiende als antipode van het vigerende 'individualistisch humanisme', namelijk 'een sociaal humanisme'.

\section{Een alternatief voor individualisme en} anti-klerikalisme: een 'sociaal humanisme' (1960-1961)

\section{Naar een ander humanisme}

Meer en meer leden begonnen zich af te vragen of de individualistische aanpak en de boven de maatschappelijke realiteit zwevende ingesteldheid eventueel niet verantwoordelijk waren voor de gebrekkige representativiteit van het HV. Voor hen was het duidelijk dat de grote massa niet aangesproken werd door het draadloze atomisme die de vereniging van oorsprong kenmerkte. Waaruit bestond dat humanistische gedachtengoed nu eigenlijk? Het $\mathrm{HV}$ moest een identiteit krijgen wilde men de onkerkelijke massa aanspreken. Vooral André Vanhassel, Jaap Kruithof en Leo Apostel zouden hieromtrent de degens met het establishment van het verbond kruisen. In hun kielzog maakten vele anderen hun grieven in verband met de toenmalige gang van zaken binnen het $\mathrm{HV}$ openlijk bekend.

Vanhassel beet de spits af met een aantal publicaties in het verbondsblad Het Vrije Woord $^{(23)}$, waarin hij virulente aanvallen lanceerde op het reilen en zeilen van het HV. Vooral het stilzwijgen op sociaal vlak en het ervoor verantwoordelijk gestelde individualisme moesten het ontgelden. Vanhassel hield een uitdrukkelijk pleidooi voor een diepgaande bezinning op algemeen menselijke en concrete problemen waarmee hij een duidelijk sociale invulling gaf van het humanisme dat tot dan toe onverenigbaar bleek te zijn met de vigerende ideologie van de vrijblijvende houding. Enkel duidelijke stellingnamen op maatschappelijk vlak zouden de meerderheid van de onkerkelijken naar het HV kunnen brengen. Met de door intellectualisme gekenmerkte debatten-en lezingencultuur als leidraad voor de individualistische opbouw van de eigen levensbeschouwing was men gedoemd een minoritaire elitegroep van goedmenende intellectuelen te blijven.

Dezelfde stellingen konden in grote lijnen ook teruggevonden worden bij Kruithof, zij het dat hij er nog een dimensie aan toevoegde: het idee van een gezamenlijk front met progressieve katholieken. Kruithofs gecontesteerde discours verklaarde de klassieke tegenstelling tussen klerikalisme en anti-klerikalisme, nu het schoolpact net was afgesloten, voor dood en verving deze 'breuklijn' door de tegenstelling tussen progressisme en conservatisme. Hij liet dus geen twijfel bestaan over het failliet van de klassieke anti-klerikale en individualistische vrijzinnigheid en kwam er tevens onverholen voor uit aan het $\mathrm{HV}$ een sociaal-linkse signatuur te willen geven, buiten de enge grenzen van de partijpolitiek om, dat terzelfdertijd ook de brug wilde slaan naar progressieve elementen binnen de katholieke kerk ${ }^{(24)}$.

Tenslotte was er de ietwat complexere benadering van een andere kritische protagonist, Apostel ${ }^{(25)}$. Ook voor hem drong een synthese en duidelijke plaatsbepaling van het humanisme zich op. Hij zag het echter nog ruimer dan Vanhassel en Kruithof. Daar waar deze twee laatsten een marxistische invulling wensten te geven aan het humanisme, zocht Apostel daarentegen naar een. synthese van verschillende humanismen waaronder zowel het individualistische, het christelijke als het marxistische 


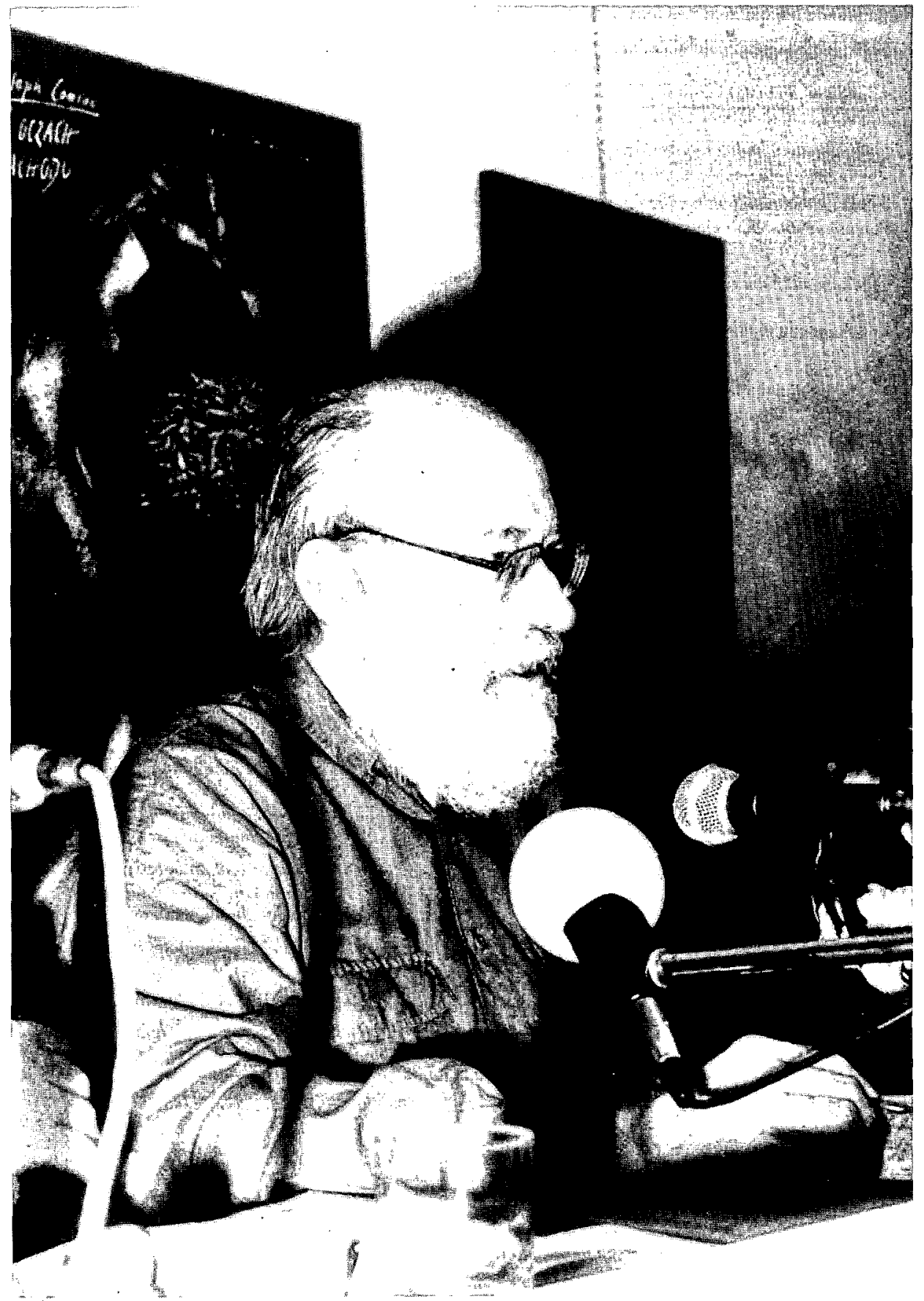

Voor Leo Apostel moest het humanisme zowel individualistisch als collectivistisch zijn (Humanistisch Verbond, Antwerpen) 
humanisme. Apostel pleitte met andere woorden samen met Vanhassel en Kruithof wel voor een socialer humanisme, maar niet voor een sociaal humanisme 'tout court'. Het humanisme zou voor hem dus zowel individualistisch als collectivistisch moeten zijn. Apostel wilde in het verlengde hiervan, net als Vanhassel en Kruithof, concreet-maatschappelijke doeleinden zoeken waarmee alle humanisten eensgezind in het strijdperk zouden kunnen treden. Hij lanceerde daarbij een aantal thema's zoals de emancipatie van de vrouw, de strijd voor geestelijke gezondheid - die moest leiden tot zelfbevrijding van alledaagse angsten door de oprichting van centra voor curatieve en preventieve geesteshygiëne - het ijveren voor betere intermenselijke relaties zoals de betrekkingen tussen werkgever en werknemer en de noodzaak tot algehele ontwapening ${ }^{(26)}$. Zodoende zou een grondige en systematische analyse van de concrete maatschappij en de verhouding van het humanisme tot die maatschappij een nieuwe ideologie mogelijk maken waarmee men uiteindelijk de daad bij het woord zou kunnen voegen.

In navolging van het discours van deze protagonisten formuleerden anderen diverse voorstellen voor concreet-maatschappelijke doelstellingen als alternatief voor het doorgedreven individualisme. Het Gentse HV-lid Robert Cliquet bijvoorbeeld bepleitte de oprichting van verschillende werkgroepen die bepaalde problemen zouden onder de loep nemen, teneinde praktische wenken en richtlijnen uit te stippelen waaraan de onkerkelijke bevolkingsgroep een houvast zou hebben. Hij dacht daarbij aan de oprichting van een commissie, die zich zou bezighouden met het bestuderen van problemen in verband met levensbeschouwelijke verhoudingen bij een verdere federalisering van het Belgische staatsbestel ${ }^{(27)}$. Eerder al hadden HV-leden als Walter Debrock en Herman Claeys getracht op het belang van een concreet standpunt inzake deze materie te wijzen ${ }^{(28)}$. Pierre Van Rompaey, HV-lid en ondervoorzitter van de sedert 1955 bestaande Belgische Vereniging voor Seksuele Voorlichting vroeg zich af waarom het HV steeds obstinaat onverschillig was gebleven voor het werk van deze vereniging. Ook hij kaderde dit in de noodzaak van een praktischer en daadwerkelijk humanisme, gezien volgens hem:

"...sommigen verzadigd raken van het vele discussiëren op een abstract niveau, dat vooral van aard is om aan te tonen hoe divers 's mensen meningen kunnen zijn en hoe moeilijk het is een lijn te trekken in een groepering als het Humanistisch Verbond" en "nu kan zoiets verbazend interessant zijn voor een elite; de massa zal het nooit aanspreken"(29).

Van Rompaey raakte net als Kruithof en Apostel ook het thema van de emancipatie van de vrouw aan. Zowel op het vlak van de emancipatie als van de seksuele moraal zou vooruitgang enkel mogelijk zijn door een verandering van de economische, sociale en politieke structuren $^{(30)}$. Het Blankenbergse HV-lid Phliep Polk stelde zich dan weer de vraag waarom geen stelling zou kunnen genomen worden inzake bijvoorbeeld kernproeven en democratisering van het onderwijs. Hij sprak er zich ook onomwonden voor uit dat de ideologie van het $\mathrm{HV}$ zou moeten gericht zijn op het ingrijpen in de maatschappelijke structuur gezien de huidige economische verhoudingen het individu verhinderden zich ten volle te ontplooien. Dit mocht voor hem zonder enig probleem ten koste gaan van een gegarandeerd ledenverlies dat eerder als een noodzakelijk kwaad werd gezien $^{(31)}$.

Daarmee zijn de voornaamste kritiekpunten op de gang van zaken in het $\mathrm{HV}$ weergegeven, maar is nog niet de vraag beantwoord waarom deze afwijkende tendensen zich juist vanaf 1958 openbaarden. Dat jaar was inderdaad niet toe- 
vallig. Het is onloochenbaar dat de afsluiting van het schoolpact ${ }^{(32)} \mathrm{en}$ de eruit voortvloeiende neutralisering van het anti-klerikalisme als bindingscriterium van het humanisme zowat de aanleiding is geworden tot dit debat. Het is immers niet toevallig dat polemieken over maatschappelijke kwesties zich vlak na het schoolpact openbaarden. Zo zou de kwestie amnestie eind ' 59 voor de eerste maal aanleiding geven tot een-polemiek tussen zij die vonden dat een stellingname inzake actuele gebeurtenissen een noodzakelijkheid was en zij die vonden dat het $\mathrm{HV}$ als levensbeschouwelijke en breuklijnenoverkoepelende organisatie zich niet met maatschappelijke tumulten in te laten had ${ }^{(33)}$. Hetzelfde herhaalde zich toen de Antwerpse afdeling van het $\mathrm{HV}$ werd uitgenodigd door het comité Geen Talentelling om mee te werken aan de boycot van de fameuze talentelling van $1960^{(34)}$. Deze kwesties gaven in alle geval aanleiding tot de oprichting van een studiecommissie, niet toevallig onder leiding van Vanhassel, met als bedoeling tot een duidelijker afbakening te komen van wat de humanisten nu eigenlijk verbond ${ }^{(35)}$. Wat er van die commissie geworden is verzwijgen de bronnen, maar men kan aannemen dat deze een slag in het water was. Dat blijkt immers uit het feit dat in 1960 de roep naar een synthese van het humanistische gedachtengoed luider dan ooit tevoren klonk.

\section{Individualistisch of sociaal humanisme?}

Vanhassel kon zijn initiatief dan ook veel succesvoller hernemen toen hij eind 1960 voorzitter werd van de Antwerpse afdeling van het $\mathrm{HV}$ en het bestuur ervan omgevormd werd tot een permanente studiecommissie, die maandelijks samenkwam om actuele gebeurtenissen vanuit humanistisch standpunt te analyseren.
Traditionele spreekbeurten met uitgesproken academische inslag werden afgeschaft en ruimden plaats voor forums en interactieve debatten die moesten toelaten een positieve, concrete en gemeenschappelijke inhoud voor het humanisme uit te werken. Het concept van een 'sociaal humanisme' werd hierbij niet langer geschuwd. Naast de Antwerpse HV-bestuursleden Kruithof en Vanhassel verdedigden ook sprekers als Ernest Mandel en vooral Etienne Scholliers (die niet toevallig juist dat jaar samen met Kruithof bestuurslid werd van de Antwerpse afdeling ${ }^{(36)}$ ) een humanisme op marxistische grondslag. Zo eindigde een spreekbeurt van Scholliers hieromtrent op een debat met als niet mis te verstane conclusie dat een werkelijk humanisme zich niet kon onthouden van concrete stellingnamen gezien het zich moest bekommeren om de concrete aliënatie van de individuen. Tegenover het individualisme had de humanistische moraal tot doel de bevrijding van de enkeling door de bevrijding van allen. Om de mens te vermenselijken diende men eerst zijn omstandigheden te vermenselijken. Dat was het doel van een actief humanisme dat een marxistisch humanisme zou zijn ${ }^{(37)}$. In mei 1961 vond dan de apotheose plaats: het denk- en discussiewerk werd voor de eerste maal gesynthetiseerd in een plaatselijk ontwerp van princiepsverklaring dat duidelijk de sociale gezindheid van het gros van de Antwerpse bestuursleden verried. De verklaring was tot stand gekomen na een 'heroïsch'debat waarbij de vroege stichters als Dille en Cuypers uiteindelijk de duimen moesten leggen. Het humanisme werd heel duidelijk gedefinieerd als een integraal-menselijke houding die in het sociale wortelde en zich op sociaal gebied te realiseren had. Men benadrukte zelfs zonder scrupules de duidelijke noodzaak van een overgang van de vigerende 'bourgeoisievrijzinnigheid' naar wat men een 'arbeidersvrijzinnigheid' noem- 
$\mathrm{de}^{(38)}$. Het klassieke individualisme werd in deze princiepsverklaring verworpen en in de plaats werd duidelijk gesteld dat de mensheid zich enkel ten volle kon ontplooiien als een collectiviteit van ontwikkelde individuen. De menselijke betrekkingen dienden dusdanig georganiseerd te worden dat ze een maximale ontplooiingsmogelijkheid gaven aan elke enkeling.

De 'new look'die de Antwerpse afdeling onder het voorzitterschap van Vanhassel had aangenomen zou duidelijk vruchten afwerpen. In het jaar 1961 steeg de belangstelling zienderogen. Op de bestuursvergadering van 11 januari 1961 werd reeds gesproken van een zeer talrijk publiek dat door de lopende debattenreeks werd aangetrokken. Plannen werden opgevat voor het uitgeven van populariserende brochures en pamfletten en deze op zo groot mogelijke schaal te verspreiden ${ }^{(39)}$. Volgens Vanhassel bereikte men in de loop van dat jaar in toenemende mate mensen uit arbeiderskringen ${ }^{(40)}$.

De belangstellingsciffers bevestigen duidelijk de opwaartse trend: forums over de houding van het humanisme tegenover de katholieken en van het wetenschappelijke humanisme ten aanzien van de godsdienst, net als debatten met Mandel, De Coninck en Vanhassel zelf haalden nooit eerder bereikte aantallen van 200 belangstellenden. Gemiddeld werden uiteindelijk in dat bewuste jaar 133 aanwezigen per activiteit opgetekend. Dat was wel een significante stijging tegenover het jaar ervoor toen men gemiddeld slechts 70 aanwezigen per activiteit telde. Wanneer men deze cijfers echter met die van andere afdelingen vergelijkt, is de discrepantie nog uitgesprokener. De Gentse afdeling, die in de jaren ' 50 het grootste aantal leden vertegenwoordigde, volgde die stijgende trend niet: in 1959 haalde men nog gemiddeld 48 belangstellenden op de activiteiten en in het jaar 1961 bleef dit min of meer stabiel op 51 .
Brussel en Brugge als de derde en vierde grootste afdeling vielen zelfs zienderogen terug: Brugge dat in 1959 nog gemiddeld 47 aanwezigen kon verwelkomen diende zich in 1961 met nog 32 tevreden te stellen. Daarenboven vielen ook het aantal activiteiten spectaculair terug: in 1959 nog 13, in 1960 en 1961 nog respectievelijk 1 en 2 . Brussel hield met gemiddeld 33 aanwezigen per activiteit nog net de helft over van 1959 toen het nog prat kon gaan op een gemiddeld aantal van 66 . Het aantal activiteiten bleef wel gelijk ${ }^{(41)}$.

Hoe reageerde het hoofdbestuur op deze ontwikkelingen? Was het bereid om, door de balans in het voordeel van een 'sociaal humanisme' te doen doorslaan, aan zijn oorspronkelijke doelstellingen te verzaken met het risico de meer liberale strekking in het $\mathrm{HV}$ voor het hoofd te stoten?

Een maand nadat de Antwerpse afdeling een eerste poging tot synthese had gedaan, stelde de beheerraad van het $\mathrm{HV}$ zich uiterst behoedzaam op. Op de vergadering van 17 juni 1961 werd duidelijk gesteld dat de uitdieping van de humanistische standpunten niet ten koste mocht gaan van de oorspronkelijke ruimheid van de princiepsverklaring. Er zou dan ook in gesloten commissie op toegezien worden dat aan de algemene princiepsverklaring niet getornd werd ${ }^{(42)}$. Significant hiervoor was het humanistische congres van Blankenberge, begin 1961, waar zelfs concrete voorstellen tot stellingname inzake atoomontwapening, geboorteregeling en een preventieve politiek voor geesteshygiëne sterk werden aangevochten. Toen Apostel zich uitsprak voor een unilaterale ontwapening werd geopperd dat een stellingname terzake, in de ideologie van het HV besloten lag. Ook een stellingname ten voordele van een geboorteregelingspolitiek werd afgewezen vermits sommigen hiertegen bezwaren hadden op grond van het feit dat deze heel 
individuele motieven had die ieder voor zichzelf moest verantwoorden. De door Apostel sterk voorgestane voorstellen ten voordele van een motie inzake een algemene preventieve politiek voor geesteshygiëne droeg evenmin de algemene goedkeuring weg ${ }^{(43)}$. Men bleef aldus grotendeels vasthouden aan de neutraliteitspolitiek op maatschappelijk vlak. Cuypers zou trouwens ook, in een hoofdartikel van Het Vrije Woord van 15 mei 1961 (dus een dag vóór de beruchte synthese van de Antwerpse afdeling), nog eens duidelijk herhalen dat stelling nemen op politiek-maatschappelijk vlak een levensbeschouwelijke vereniging overbodig zou maken ${ }^{(44)}$. Deze 'non-interventie'-politiek bleek, gezien de toenmalige crisissituatie in het verbond, ook hard nodig. Aan de ene kant van het humanistische spectrum stond het individualistische humanisme' van de liberale, vooral Gentse strekking en aan de andere kant dan weer het 'sociale humanisme' van de marxistische, vooral Antwerpse strekking. De beheerraad van het HV zou deze strijd wel gedogen op het plaatselijke vlak, maar geenszins in eigen nationale kring. De verwachting van de Antwerpse bestuursleden dat hun voorbeeld bij het centrale bestuur navolging zou vinden werd niets. De vraag naar een algemene stelling die het gezamenlijke standpunt van het verbond zou uitdrukken viel bij het hoofdbestuur steeds opnieuw in dovemans oren. Een marxistische interpretatie van het humanisme was immers onverenigbaar met de uitermate ruime en adogmatische interpretatie die de stichtersvrijmetselaars eraan gegeven hadden. Zo stelt Cuypers over de Antwerpse perikelen in een brief:

"Antwerpen vormt een zeer speciaal geval met zïn marxistische gelovigen. Let wel: ik ben zelf van oordeel dat het marxisme NU eens een leidende rol zal te vervullen hebben maar het wil er bij hen niet in dat het, zoals alle opvattingen over een eeuw niet reactionair zal worden. Dan kunnen wij evengoed katholieken worden..."

In gelijkaardige zin is er ook een verontwaardigde brief van HV-lid en directeur van de Lierse rijksmiddelbare school, Renaat Merecy: "Het marxistisch standpunt is al te zeer een sterk geaccentueerde achtergrond van onze houding geweest en zulks kan de niet-marxistische socialisten en liberalen ergeren. Marxisme kan toch ook als een dogmatische, conservatieve verstarring aangezien worden..."

Merecy's vrees dat de liberalen zouden afgeschrikt worden was in alle geval niet ongegrond. Het blauwe bastion in de Gentse afdeling had de Antwerpse tendens in de richting van een 'sociaal humanisme' steeds met argusogen bekeken. Eind 1961 was de situatie echter precair geworden. In interne liberale kringen dweepte Vlaams-liberaal voorman Albert Maertens immers met het idee van een afscheuring van de liberale fractie. Reeds eerder had Maertens ook zijn steun aan de humanistische radio- en televisieuitzendingen dreigen op te schorten omdat hij die te links geïnspireerd achtte. Het was vooral dankzij bemiddeling van Adriaan Verhulst, die toen voorzitter was van de Gentse afdeling, dat een schisma vooralsnog werd bezworen. Verhulst had dit gekund door te stellen dat op nationaal niveau nog niets beslist was en dat de liberalen zich in alle geval massaal zouden verzetten tegen iedere poging om de sociaal-vooruitstrevende gerichtheid in een algemene beginselverklaring vast te leggen. Vooral het argument dat de vrijzinnigen sterk zouden moeten staan bij de mogelijke culturele autonomie voor Vlaanderen bleek doorslaggevend om de eenheid binnen het verbond als enige organisatie op levensbeschouwelijke grondslag te bewaren ${ }^{(47)}$. Maertens zou zich alvast met deze argumentatie verzoenen hoewel hij eind 1961 nog een eigen idee van 


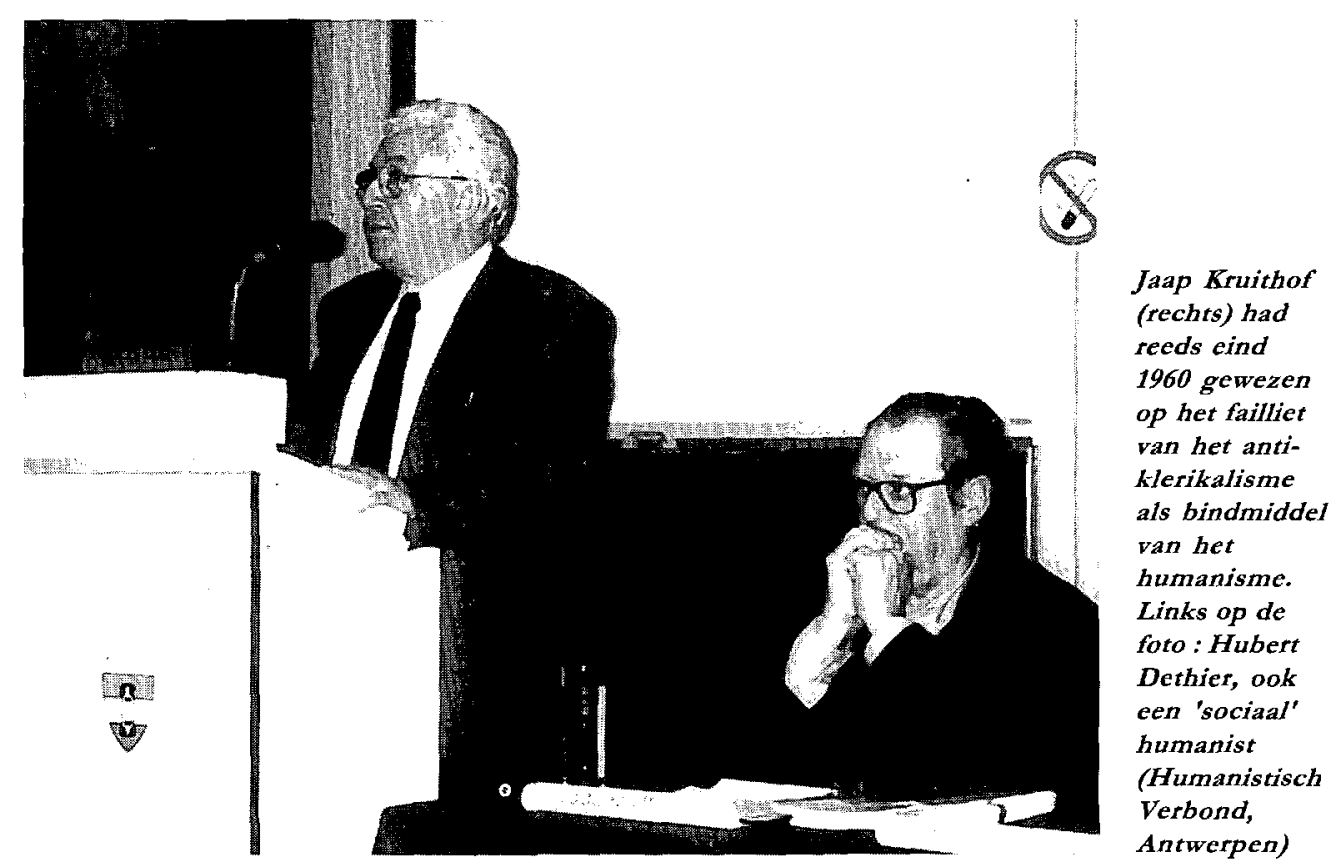

een organisationele structuur voor het $\mathrm{HV}$ had. Hij pleitte ervoor van het $\mathrm{HV}$ een federalistische structuur te maken met daarin een liberale strekking die haar sociaal-politieke theorieën zou kunnen verkondigen in de liberaalvooruitstrevende Julius Vuylsteke-kring, terwijl de socialistische strekking hetzelfde zou kunnen doen via een gelijkaardige kring (een Karl Marx-kring in Maertens' woorden). Het HV zou deze kringen overkoepelen en zodoende zelf neutraal blijven ${ }^{(48)}$. Dat voorstel lijkt echter, voor zover de bronnen het vermelden, nooit ter tafel te zijn gebracht.

\section{Anti-klerikalisme of doorbraak?}

Was het individualisme aldus nog uitermate taai, dan was ook het daarmee verbonden antiklerikalisme en zelfs de anti-godsdienstigheid verre van verdwenen. De kenmerken van een sociaal humanisme vielen grotendeels (maar niet noodzakelijk) samen met het idee van een progressief front met zekere groepen van katholieken die binnen de bestaande Kerk ageerden tegen de zogenaamde 'dwanggodheid'. Vooral Apostel en Kruithof manifesteerden zich meer dan wie ook als openlijke voorstanders. Kruithof had reeds eind 1960 uitdrukkelijk gewezen op het failliet van het anti-klerikalisme als bindmiddel van het humanisme en de potentiële vruchtbaarheid van een toenadering tot progressieve katholieken met wie hij zich naar eigen zeggen op sommige punten meer verwant voelde dat met'conservatieve Voltairianen ${ }^{\prime(49)}$. Begin 1961 toetste Apostel als voorzitter van de Brusselse afdeling van het $\mathrm{HV}$ de theorie aan de praktijk door een openbaar debat te organiseren waarop hij zelf in discussie trad mèt de jezuïet en hoogleraar Roger Leys en met Alexander Johannes Bronkorst, hoogleraar bij de Protestantse Theologische Faculteit, over 'De 
Toekomst van Religie en Vrijzinnigheid'. Met dit debat wilde men in progressistische gelovige en vrijzinnige kringen een bezinning op gang brengen over eventuele gemeenschappelijke punten. Met groepen die zich binnen de Kerken verzetten tegen de stugge dogmatiek moest een potentiële samenwerking in het verschiet liggen. Voor Leys was een uitzuivering van de standpunten van de strijdende partijen noodzakelijk. Zowel links als rechts bleven opgesloten in een verstarde anti-houding zodat moest gestreefd worden naar een positieve zelfverwerkelijking van de mens. De vrijzinnigheid moest positief gericht zijn op een samenleving die de ontplooiing van menselijke waarden mogelijk maakte. De godsdienst moest zich volgens Leys bewust zijn van de eigen structuur van menselijke waarden binnen de religie, hetgeen zou toelaten om, hoezeer de fundering ook verschilde, voor die gemeenschappelijke waarden met humanisten samen te werken. Ook de protestantse hoogleraar Bronkhorst zag in de toenmalige bedreigingen der mensheid redenen tot wederzijdse samenwerking en waardering ${ }^{(50)}$. Ondanks veel goede wil stuitte het initiatief echter stante pede op verzet van de beheerraad van het HV. Deze wees er immers nadrukkelijk op dat dergelijke gesprekken dienden beperkt te blijven tot de privékring en niet in het openbaar konden plaatsvinden ${ }^{(51)}$. De Brusselse afdeling die het bewuste forum met Apostel, Leys en Bronkhorst organiseerde, drukte dan ook dadelijk haar ongenoegen uit:

"Ons plaatselijk bestuur heeft hierover zijn verwondering uitgedrukt. Beoefenaars van het vrij onderzoek willen immers geen enkele samenspraak of debat ontwijken, hebben geen minderwaardigheidscomplex ten aanzien van katholieken en zijn ervan overtuigd dat zulke gesprekken nuttig zijn"(52).

Andere individuele reacties toonden aan dat men, zoals vanuit het hoofdbestuur bekendgemaakt, niet al te voortvarend mocht zijn met deze toenaderingen. Zo haalde nationaal-secretaris Herman Buskens in Het Vrije Woord van maart 1961 zwaar uit naar de aanhaligheid in sommige katholieke middens die volgens hem erop uit waren aan een soort van assimilatiepolitiek te doen waarbij het humanisme stilzwijgend van zijn ware aard en inhoud zou beroofd worden. Hij pleitte voor een humanisme dat absoluut onverenigbaar was met het aanvaarden van de mogelijkheid van een hogere macht en toonde zich afkerig van iedere vorm van godsdienst of mystiek tout court. Buskens kwam tenslotte zonder scupules uit voor een radicale anti-godsdienstige houding: "Zoals de gelovige spijts alle mogelijke eerbied, niet zal nalaten ons te beklagen en voor onze bekering te bidden, zo zullen wij, spijts alle wederkerige eerbied, niet nalaten het jammer te vinden dat iemand zich zo kan vergissen door een ideologisch gevaarlijke leer aan te hangen. En door zo te doen zijn wij anti-godsdienstig maar niet méér anti-godsdienstig dan de katholiek anti-vrijzinnig is..."(53)

Eerder had Pierre Deleu voor de Antwerpse afdeling betoogd dat een vrijzinnig humanisme niet alleen noodzakelijkwijze anti-godsdienstig moest zijn, maar tevens ook iedere vorm van geloof in het sacrale uit hoofde van het humanisme diende te verwerpen ${ }^{(54)}$.

Dit debat bereikte zijn culminatiepunt tijdens een forumavond voor de Antwerpse afdeling op 18 april 1961. Deelnemers waren Cuypers, Scholliers, Hugo Uyterhoeven, Louis Van Swinderen en twee protagonisten, Kruithof en Buskens. Een afdoend antwoord op de vraag of samenwerking met progressieve katholieken vruchtbaar was kwam er evenwel niet. Wel werd gewaarschuwd voor de opvallende welwillendheid die het Vaticaan in die jaren ten aanzien van andersdenkenden aan de dag 
legde. Men kaderde dit proces in de westerse blokvorming tegen het communisme. Het anticommunisme werd verworpen in de zin dat het door reactionaire groepen te pas en ten onpas werd toegepast op al wat hun belangen kon bedreigen. Voorts hekelde men de verdraagzaamheid die sommige katholieke priesters ten aanzien van het $\mathrm{HV}$ tentoonspreidden. Men zag hierin een strategie om het proselitisme ook in vrijzinnige rangen te kunnen doorzetten:

"Ongetwiifeld gaat het hier dikwijls om berekende pogingen die alleen maar een democratische new look zijn van de missie- en inquisitiezending die de Katholieke Kerk zich blijft toekennen"(55). Kortom, het was duidelijk dat de tijd nog niet rijp was om dergelijke samenwerkingsverbanden aan te gaan. Net als een openlijke stellingname ten voordele van politiek-maatschappelijk kwesties een potentiële breuk met zich kon brengen, zou ook een verklaring ten voordele van de doorbraak naar andersdenkenden toe de toch al broze eenheid van het verbond aan het wankelen kunnen brengen. Enerzijds zou met een veroordeling van het anti-klerikalisme naar Kruithofs voorbeeld de zin van een $H V$ voor vele mensen sterk aan belang inboeten. Anderzijds moest men erop letten geen expliciete anti-religieuze of antigodsdienstige stelling naar het voorbeeld van Deleu of Buskens in te nemen, gezien het HV vele leden had die deze houding als archaïsch en eigen aan de 'bourgeoisievrijzinnigheid' beschouwden. De vrijblijvende houding was dus ook op dit vlak de conditio sine qua non voor het verdere bestaan van het $\mathrm{HV}$.

\section{Conclusie}

Bij wijze van besluit kan aldus gesteld worden dat voor het hiaat tussen het aantal onkerkelijken en de effectieven van het humanistische verenigingswezen een mea culpa geslagen kon worden. Het 'sociale humanisme', met als meest mondige protagonisten Vanhassel, Kruithof en Apostel, bood een alternatief voor het humanisme van het individualistisch en universalistisch ingestelde $\mathrm{HV}$-establishment. Ondanks zichtbạre successen in het aanspreken van een bredere massa bleef deze laatste echter doof voor de vernieuwingstendens. De voorstanders van een 'sociaal humanisme' hadden wel het recht hun mening ten persoonlijken titel te uiten en zelfs in de praktijk te brengen, doch van zodra zij daarmee aanspraak maakten op een eventuele geldigheid van een bepaalde stelling voor het $\mathrm{HV}$ als geheel, was een duidelijk njet het antwoord. De houding van de Antwerpse afdeling en van enkele dissidente discipelen was doodgewoon niet representatief voor het $\mathrm{HV}$, ongeacht of het daarmee nu al dan niet successen boekte. Het 'sociale humanisme' werd aldus als het ware geïntegreerd in datgene waar men juist tégen ageerde, namelijk het vrijblijvende systeem. De princiepsverklaring bleef dan ook zoals ze van in den beginne door de stichtende vrijmetselaars geconcipieerd was. In die zin hadden de vernieuwingsgezinden, zowel wat hun streven naar een 'sociaal humanisme' als het grotendeels daarmee samenhangend progressief front met andersdenkenden betrof, toch duidelijk het onderspit gedolven. 
(1) J. FRANSEN, Het Humanistisch Verbond: Ontstaan, uitbreiding en crisis (1951-1961), VUB, onuitgegeven licentiaatsverhandeling, 1997, 125 p. (+ bijlagen).

(2) J. FRANSEN, Het Humanistisch Verbond: Ontstaan, uitbreiding en crisis (1951-1961). In: Belgisch Tijdschrift voor Nieuwste Geschiedenis, 1998 (datum nog ongekend).

(3) In 1947 werd het aantal mensen zonder een kerkelijke gezindte geraamd op $17 \%$ van de Nederlandse bevolking. Dit cijfer is gebaseerd op door het CBS gepubliceerde gegevens van de 10jarige volkstellingen. Zie H. FABER, T.T. TEN HAVE, J.P. KRUIJT e.a., Ontkerkelijking en buitenkerkelijkheid in Nederland, tot 1960, Assen: Van Corcum \& Comp. NV, 1970, p. 28.

(4) P. DERCKX \& B. GASENBEEK, Jaap Van Praag, Vader van het Moderne Nederlandse Humanisme, Utrecht: De Tijdstroom, Humanistische Bibliotheek, 1997, p. 54 .

(5) T. FLOKSTRA \& S. WIELING, De Geschiedenis van het Humanistisch Verbond, 1946-1986, Utrecht: Humanistisch Verbond, De Walburg Pers, p. 21.

(6) J. VAN PRAAG, Modern Humanisme, een Renaissance? Amsterdam: Contact, 1947, p. 216.

(7) J. TYSSENS, Een Vlaamse inbreng in de vrijzinnige actie rond de schoolkwestie in de jaren ' 30 . Van de Vrienden van het Officieel Onderwijs naar het Algerneen Verbond ter Bevordering van het Officieel Onderwijs. In: Belgisch Tijdschrift voor Nieuwste Geschiedenis, 24(1993)3-4, p. 393.

(8) J. FRANSEN, Het Humanistisch Verbond[...], pp. 35-38.

(9) Prof. Dr. De Coninck 1909-1988. Bioloog, Humanist, 't Zaller, Gent: Bestuur Bond Oudleden 't Zal Wel Caan n.a.v. tentoonstelling over prof. De Coninck, 1988, pp. 43-44.

(10) Voor een recent overzicht daaromtrent zie E. WITTE, Pierre-Théodore Verhaegen en de vrijmetselarij. In: Pierre-Théodore Verhaegen 17961862, Brussel: VUBPRESS, 1996, pp. 51-64.

(11) Dille was directeur van de Hogere en Middelbare School voor Handel en Administratie, zie W. MATTHIJS, F. MOERKERKE \& I. VAN HOOF (eds.), Liber Amicorum Robert Dille, Antwerpen: HV, 1992, p. 9.

(12) Cuypers was sedert 1947 studieprefect van het Atheneum van Hoboken, zie E. WILLEKENS, Karel Cuypers. 1902-1986. Profiel van een Humanist, Brussel: Vrijzinnig Documentatiecentrum Karel Cuypers, 1987, p. 22; Van Laar werd met ingang van april 1950 hoofdinspecteur van het Antwerps Stedelijk Onderwijs, zie H. VAN DAELE, 150 jaar Stedelijk Onderwijs te Antwerpen 1819-1969, Stad Antwerpen, 1969, p. 258; Camerlinckx was leraar aan de Antwerpse Hogere Handelsschool, A.B. was leraar muziekgeschiedenis aan het Antwerps
Conservatorium. Zie Privéarchief, L. De ConinckWuytens.

(13) Ruyssen was hoofd van het laboratorium farmaceutische en medische chemie aan de RUG, zie Liber Memorialis 1930-1980, Faculteit der geneeskunde, Gent: Alumni Fonds,1980, p. 349; De Coninck stond aan het hoofd van de afdeling morfologie van de afdeling zoölogie aan de RUG, zie HV, W. Matthijs, 50/C/530114, brief De Coninck aan Dille, 14-1-53; Thiery was directeur van de Gentse Stadsbibliotheek en Hebbelinck tenslotte leraar aan het Atheneum van Gent. Zie Privéarchief, L. De Coninck-Wuytens.

(14) Flam en Hofmans waren leraars aan respectievelijk het Atheneum van Brussel en Sint-Gillis, Bouckaert was studieprefect van het Etterbeeks Atheneum, zie Privéarchief, L. De Coninck-Wuytens; Herreman tenslotte was ambtenaar bij de Senaat, zie F. CLOSSET, Reimond Herreman, Brussel: A. Manteau NV, 1961, p. 6

(15) Privéarchief, L. De Coninck-Wuytens.

(16) In tegenstelling tot Nederland zijn er voor het aantal buitenkerkelijken in België in de jaren ' 50 geen degelijk beargumenteerde cijfers voorhanden. In humanistische kringen zelf spreekt men in de jaren '50 voortdurend van zowat 'de helft van de bevolking'. Veel hangt uiteraard af van de criteria die men daarvoor gebruikt. Een wat objectievere aanduiding wordt gevonden bij de Gentse historicus Jan Dhondt. Hij schatte, met veel zin voor nuance, het aantal 'kerkelijken' begin jaren '50 nog slechts op 47 of $48 \%$ van de bevolking. Zie: J. DHONDT, 'Over onkerkelijkheid'. In: Bevrijdend Denken, Amsterdam - Antwerpen: Wereld - Bibliotheek, 1956, p. 100.

(17) Voor een totaaloverzicht van de verspreiding van het humanistische verenigingswezen verwijs ik opnieuw naar: J. FRANSEN, Het Humanistisch Verbond[...], pp. 43-48.

(18) J. FRANSEN, Het Humanistisch Verbond[...], p. 50.

(19) R. DEMEESTER, Het Humanistisch Verbond in het voorbije verenigingsjaar. In: Diogenes, 4-57, p. 60 .

(20) Privéarchief, Jan Engelen, 0035: Brief Demeester aan afdelingen, 17.9.58.

(21) AMSAB-CLM-Antwerpen, Michel Oukhow, 9.196: Verslag algemene vergadering $H V, 23.5 .59$.

(22) Voor 1956 zie: R. DEMEESTER, Het Humanistisch Verbond[...], p. 62; voor 1960 zie: AMSAB-CLMAntwerpen, archief M. Oukhow, 18.345: Overzicht activiteiten plaatselijke afdelingen jaar 1960.

(23) Mooie voorbeelden zijn onder andere: Vlaamse vrijzinnigheid. In: Het Vrije Woord, 2.2.60, pp. 3-4; Onze taak betreft het wezenlijke. In: Het Vrije Woord, 5.3.60, pp. 49-51; Onze Nationale Censuur. In: Het Vrije Woord, 4.6.60, pp. 145-148; Wat is Vrijzinnigheid? In: Het Vrije Woord, 1.12.60, pp. $281-286$. 
(24) AMSAB-CLM-Antwerpen, M. Oukhow, 9.196: verslag spreekbeurt Kruithof omtrent 'buitenkerkelijkheid en vrijzinnigheid' 18.10.60.

(25) AMSAB-CLM-Antwerpen, $M$. Oukhow, 9.196: verslag spreekbeurt Apostel omtrent 'Wat is Vrijzinnigheid', 16.11.60.

(26) Afdelingsleven. Afdeling Antwerpen, Wat is Vrijzinnigheid? In: Het Vrije Woord, 1.12.60, p. 296.

(27) R. CLIQUET, Federalizatie en levensbeschouwelijke verhoudingen. In: Het Vrije Woord, 1.6.60, p. 149.

(28) H. CLAEYS, Federalisme, een humanistische oplossing? In: Het Vrije Woord, 1.5.60, p. 119; voor W. DEBROCK zie VLC Gent, N. De Blick, map 5: Verslag spreekbeurt Debrock over 'Vrijzinnigheid en culturele autonomie', 17.11.61.

(29) P. VAN ROMPAEY, Praktisch humanisme binnen uw bereik. In: Het Vrije Woord, 1.11.60, p. 278.

(30) P. VAN ROMPAEY, Emancipatie: voor wanneer? In: Het Vrije Woord, 1.11.61, p. 257.

(31) P. POLK, Geen Politiek in het H.V.? In: Het Vrije Woord, 15.9.61, p. 222.

(32) Het compromis kwam tot stand op 6 november 1958 en werd geratificeerd op 29 mei 1959. Het was een vergelijk rond het principe van de 'vrije keuze van de huisvader'. In concreto betekende dit dat de ouders in staat werden gesteld binnen een redelijke afstand van hun woning een school te kiezen in overeenstemming met hun ideologische voorkeur. Het rijksonderwijs kon zodoende zijn historische achterstand inhalen terwijl het katholiek onderwijs d.m.v. staatssubsidies kosteloos kon worden. Daarmee werd het bestaansrecht van verschillende ideologische bevolkingsgroepen geïnstitutionaliseerd. Van belang voor dit artikel is dan ook vooral dat hierdoor een belangrijk wapen tot mobilisatie van de katholieke en vrijzinnige aanhang verloren ging. Zie: $\mathrm{E}$. WITTE, J. CRAEYBECKX \& A. MEYNEN, Politieke geschiedenis van België van 1830 tot heden. Brussel: VUBPRESS, 1990, pp. 263-264.

(33) VUB, Karel Cuypersfonds, 77: Verslag vergadering beheerraad HV, 12.12.59.

(34) AMSAB-CLM-Antwerpen, M. Oukhow, 9.196: Verslag bestuursvergadering $H V, 24.11 .59$

(35) VUB, Karel Cuypersfonds, 77: Verslag vergadering beheerraad, 12.12.59.

(36) AMSAB-CLM-Antwerpen, M. Oukhow, 17.340: Verslag bestuursvergadering HV-Antwerpen, 10.5.61.

(37) AMSAB-CLM-Antwerpen, M. Oukhow, 9. 196: Verslag spreekbeurt Scholliers over Humanisme en Materialisme, 24,1,61.

(38) A. VANHASSEL, Ter verantwoording van het Antwerps manifest: naar een positieve humanistische beweging. In: Het Vrije Woord, 15.6.61, pp. 161163.
(39) AMSAB-CLM-Antwerpen, M. Oukhow, 17.340: Verslag vergadering HV-Antwerpen,11.1.61.

(40) A. VANHASSEL, Ter verantwoording van het Antwerps manifest: naar een positieve humanistische beweging. In: Het Vrije Woord, 15.6.61, p. 166.

(41) Overzichten van activiteiten van plaatselijke afdelingen in de loop van de jaren ' 60 en ' 61 zijn te vinden in AMSAB-CLM-Antwerpen, M. Oukhow, 18.345; Voor het jaar 1959 zie VUB, Karel Cuypersfonds, 77.

(42) AMSAB-CLM-Antwerpen, M. Oukhow, 18.345: Verslag vergadering beheerraad $H V, 17.6 .61$.

(43) VUB, Karel Cuypersfonds, 77: Brief Apostel aan Schellens, 1961.

(44) K. CUYPERS, Geen politiek in het Humanistisch Verbond. In: Het Vrije Woord, 15.5.61, p. 129.

(45) HV, W. Matthijs, 60/C/620211: Brief Cuypers aan Verhelst, 11.2.62.

(46) AMSAB-CLM-Antwerpen, M. Oukhow, 9.196: Brief Merecy aan Houtmortels, 20.4.61.

(47) VLC Gent, N. De Blick, VIII2: Brief Verhulst aan Maertens, 21.10.61.

(48) VLC Gent, N. De Blick, VIII2: Brief Maertens aan Verhulst, 12.1.62.

(49) AMSAB-CLM-Antwerpen, M. Oukhow, 9. 196: Kruithof over Buitenkerkelijkheid en Vrijzinnigheid, 18.10 .60 .

(50) De Moraal in het voortgezet onderwijs. Een lofwaardig initiatief. In: Het Vrije Woord, 15.4.61, p. 110 .

(51) AMSAB-CLM-Antwerpen, $M$. Oukhow, 9.196: Verslag vergadering beheerraad, 11.3.61.

(52) VUB, Karel Cuypersfonds, 77: Brief HV Brussel aan HV nationaal, 1961.

(53) $\mathrm{H}$. BUSKENS, Zijn humanisten anti-godsdienstig? In: Het Vrije Woord, 1.3.61, p. 53.

(54) Afdelingsleven. Afdeling Antwerpen, Is heit humanisme anti-godsdienstig? In: Het Vrije Woord, 15.3.1960, p. 80.

(55) AMSAB-CLM-Antwerpen, M. Oukhow, 9.196: Verslag forum-avond over de houding van $\mathrm{HV}$ tegenover katholieken, 18.4.61. 